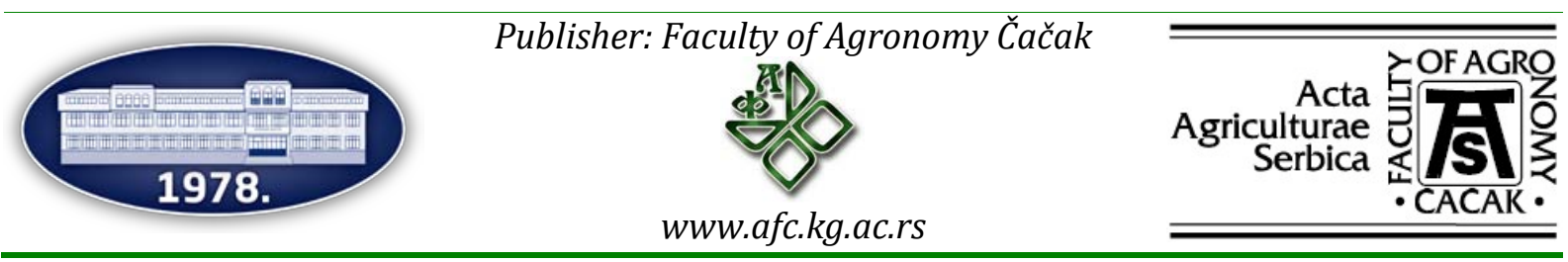

\title{
Economic aspects of vermicompost production in southern Serbia
}

\author{
Zoran Stojiljković1* , Jelena Vanovac ${ }^{2}$, Mile Peševski³ ${ }^{3}$ Jasmina Stojiljkovićc \\ Dragutin Đukićs
}

${ }^{1}$ Interspajs, d.o.o., Sutjeskina 31/1, 17500 Vranje, Serbia

2 State Audit Institution, Makenzijeva 41, 11111 Belgrade, Serbia

${ }^{3}$ Faculty of Agricultural Sciences and Food, Ss. Cyril and Methodius University in Skopje, 16-ta Makedonska brigada 3, Republic of North Macedonia

${ }^{4}$ The Academy of Applied Technical and Preschool Studies, Filip Filipovic 20, 17500 Vranje, Serbia

${ }^{5}$ Faculty of Agronomy, Cara Dusana 34, 32000 Čačak, Serbia

*Corresponding author: zoran140366@gmail.com

Received 27 February 2020; Accepted 14 April 2020

\begin{abstract}
A B S T R A C T
Given the accelerated technical and technological development in the field of agricultural production of the 21st century, which aims to increase production quantitatively, the quality of primary agricultural products is in many cases unfairly neglectedThis has directly aroused consumer awareness of the inevitable transition to purchasing products from alternative production methods (self-produced "healthy food", organic food production). For these reasons, the consumer alternative is to switch to environmentally friendly and health-safe products obtained from agricultural production and to use them in the future. A very promising product of this kind in the Republic of Serbia is vermicompost. Vermicompost is widely used in primary agricultural production: fruits and vegetables, mushroom production, horticulture, nurseries, green areas, parks, green sports fields, and in all segments of organic plant production.

The benefits that farmers have from using vermicompost are a prerequisite for this product to be marketed in Serbia. This paper describes the benefits for both vermicompost manufacturers and consumers and the wider community.

Keywords: vermicompost, organic food, variable cost, total costs, profit, producer benefit, consumer benefit.

\section{И 3 В О Д}

С обзиром на убрзани технички и технолошки развој у области пољопривредне производње 21 . века, која има за циљ квантитативно повећање производње, квалитет производа из примарне пољопривредне производње у многим случајевима је неправедно занемариван. Као директна последица тога јавила се пробуђена свест потрошача о неизбежној транзицији ка куповини производа из алтернативних метода производње (самостално произведена „здрава храна", органска производња хране). Из тих разлога алтернатива потрошача је прелазак на еколошки прихватљиве и здравствено безбедне производе добијене у пољопривредној производњи и њихова употреба у будућности. Врло обећавајући производ ове врсте у Републици Србији јесте вермикомпост.

Користи које пољопривредни произвођачи имају од употребе вермикомпоста предуслов су да се овај производ пласира у Србији. У раду су описане предности како произвођача вермикомпоста, тако и потрошача, као и шире друштвене заједнице.

Кључне речи: вермикомпост, органска храна, варијабилни трошкови, укупни трошкови, добит, корист за произвођача, корист за потрошача.
\end{abstract}

\section{Introduction}

Vermicompost is a coprolite of Californian red worms. This product is obtained by processing the nutrients that Californian worms use in their lives, and they are actually waste and are added to organized and planned production at specific time intervals (feeding Californian worms) to the "habitats" in which they live and multiply. The quality of vermicompost depends primarily on the materials that the worms processed in their lifecycle, as evidenced by the contents of certain chemical components in the final product that determine the final product and its price (total organic matter, humic acids, micro elements ...) (Lončarić et al.,
2005). The quality of the finished product depends on the manufacturing process itself, which needs to be properly designed and implemented to achieve expected and good results.

The main raw material used for the production of vermicompost is a mixture of different types of rotted manure (Vukobratović, 2008), obtained in our environment primarily from cattle. The production of vermicompost should be located next to the source of manure (livestock farms) because manure is a dangerous product that pollutes the environment (Karmakar et al., 2007) and is a cheap product with a cumbersome structure and therefore causes higher 
transport costs, thus increasing the cost of vermicompost production.

For vermicompost production, other bio-wastes found in nature are also available, including crop residues, fresh food residues, forest leaves and branches, by-products in the processing of juices and other products of plant origin, cardboard (Dragović, 2012).

According to published data (Stepanov, 2018), the annual amount of municipal waste produced in Serbia is $2,374,374$ tonnes $(0.87 \mathrm{~kg}$ per day/ capita). Serbia's Environmental Protection Agency estimates that Serbia produces about $12.5 \mathrm{~m}$ tonnes of biomass annually (with an energy potential of $63-80 \%$ ), of which: $40 \%$ of the potential is wood, and the remaining $60 \%$ is biomass from agriculture. It is also estimated that organic waste makes up the largest share of municipal waste (about 43\%), followed by cardboard and paper (about 15\%) and plastic (about 15\%) while textiles and glass account for about $5 \%$.

Depending on climatic conditions, the rate of production, the intensity of the production cycle and the manufacturer's financial capabilities, the best model of primary production of vermicompost is made. It also involves the construction of a "worm habitat", a suitable combination of different types of bio-waste as worm food, physical and chemical parameters that are necessarily controlled (temperature, \% moisture, $\mathrm{pH}$ of the substrate, exposure to direct sunlight) when worms grow (Dominguez, 2004). The final product of this production is vermicompost, an organic soil conditioner.

The production of vermicompost in the Republic of Serbia is in the initial stage of development, taking into account the possibilities for positioning and the needs of the market for this type of product. According to officially available data, this (or similar product) was momentarily registered by 8 producers in the Republic of Serbia and included in the List of Plant Nutrition Products and Soil Improvers (approved by the Ministry of Agriculture of the Republic of Serbia in December, 2018). The number of unregistered producers can only be speculated because it is assumed that they are making vermicompost as part of their own agricultural production and for their own needs and therefore they do not take an important share of the market.

The advantage of this product over products with a similar name is that it is rich in beneficial microorganisms that protect plants from various diseases, give the plant vitality and nutrients, and improve the soil. Given the potential of vermicompost and the current state of the Serbian market, production cannot meet the needs of the market. This is supported by the fact that organic plant production in the Republic of Serbia has increased over the last 6 years , with $99 \%$ of organic products being exported (EU countries), (Organic production in Serbia, 2017). Apart from these several segments of agricultural production in which vermicompost is of great use, it is also attracting new segments of consumers on the market (for horticulture, green areas and parks, nurseries, stadiums, greenhouses). These data provide great encouragement and motivation for new producers of vermicompost in Serbia.

The results obtained and the experience gained from the analyzed vermicompost production will be used to develop business plans for larger or smaller production units.

\section{Material and methods}

An economic analysis of vermicompost production and sales was made on the basis of data obtained from a small-capacity vermicomposting unit in southern Serbia. The production facilities are installed on an area of $120 \mathrm{~m}^{2}$. The annual production capacity is about $84,000 \mathrm{~L}$ of finished product (the amount of vermicompost is expressed in volume, in liters).

The location of the survey is near Vranje $(450 \mathrm{~m}$ above sea level, North latitude $42^{\circ} 33^{\prime} 15^{\prime \prime}$ East longitude 21 $53^{\circ} 50^{\prime \prime}$, climate: local, temperate continental, with long and warm summers and mild winters).

The production facility includes 6 vermicomposting units, with a volume of $20 \mathrm{~m}^{3}$, and each having the following size : length $20 \mathrm{~m}$, width $1 \mathrm{~m}$ and height $1 \mathrm{~m}$, with a concrete floor of $5 \mathrm{~cm}$ thickness.

The vermicomposting units for the conversion of organic matter into vermicompost by Californian earthworms were constructed using concrete blocks (block dimensions: length $40 \mathrm{~cm}$, width $20 \mathrm{~cm}$ and height $20 \mathrm{~cm}$ ) arranged at a height of $80 \mathrm{~cm}$ to $1 \mathrm{~m}$ the entire length of the building, without a firm connection.

The source of the raw material used for processing is near the site and comes from mini farms where cattle and sheep are raised. In particular, the observed amount of food for Californian earthworms (manure) can be produced on an average farm in Serbia (up to 50 sheep or 3-5 cows). If the required amount of fertilizer was produced on the property itself, there would be no cost to buy it. In addition to this type of raw material, apple pulp is also used; it is obtained from a fruit juice production plant located about $30 \mathrm{~km}$ from the processing site Apple pulp is basically an excellent medium for the development of Californian worms due to its $\mathrm{pH}$ value, and it bothers the juice producer who considers it waste (the vermicompost manufacturer currently procures it for free.

The first step in the production process is to form a layer of straw and manure of about 10-15 cm thickness at the bottom of the vermicomposting plant. This initial layer is well watered, and on the fifth day (in this case) worms are added in an amount of about $0.5 \mathrm{~kg} / \mathrm{m}^{2}$ over the layer of earthworm feed. Each subsequent layer of earthworm food consists of a mixture of apple pulp and manure at a ratio of $40 \%: 60 \%$. Watering is done (to avoid water from the water supply network), when it is visually determined that the waste material still needs moisture, to ensure that the organic matter "melts" and as such is acceptable for earthworms, i.e. sucked in and processed through their digestive tract because they have no teeth to chew it, . The amount of worm food processed per day is approximately equal to the weight of the worm itself (about $1 \mathrm{~g}$ ) and the end product is in the form of a coprolite (that is, about 60$70 \%$ of the food that is introduced into the worm's digestive tract).

The raw material processing and filling process takes 7-8 months to 12 months. After filling the facility, the surface layer rich in earthworms is removed and transferred to another facility where it serves as the initial layer. This avoids the acquisition of new earthworms for each subsequent facility, thus reducing investment in new and expanded production. The resulting vermicompost is removed from the facility and deposited in piles where it is dried. It is 
desirable to winterize them at low temperatures in order to make the structure of the finished vermicompost as finely divided and differentiate as possible. The next phase is the sieving of vermicompost through a sieve $(100 \%<5 \mathrm{~mm})$ and the mechanical separation of residual foreign matter and untreated elements in the final product, and also the separation of residual worms from the finished vermicompost. The last stage in the production of vermicompost is to measure and pack it in bins, polythene bags or bags. The shelf life of the finished product is estimated to be at least 2 to 3 years after being packaged in its original packaging. The calculation method was used to obtain relevant economic data. After the production cycle was completed, production calculations were made using cost data and economic results were obtained.

\section{Results and discussion}

The results were obtained in a $120 \mathrm{~m}^{2}$ production unit that included $120 \mathrm{~kg}$ of Californian earthworms. Worms process manure and multiply at the same time several times during the year.

In this study, the income from the worms obtained was not taken into account, and only the amount of vermicompost obtained was considered. The currency in which the financial values are expressed is the Euro (€).

\section{Table 1}

Production costs in the first year

\begin{tabular}{|c|c|c|c|c|c|c|}
\hline \multirow{2}{*}{ Item } & \multirow{2}{*}{\multicolumn{2}{|c|}{ Description }} & \multicolumn{4}{|c|}{ Production price of vermicompost } \\
\hline & & & $\%$ & Quantity & Price & $€$ \\
\hline \multirow{9}{*}{1} & \multicolumn{2}{|c|}{ Fixed costs (basic investment costs) } & & & & \\
\hline & 1 & Earthworm facilities & & 6 & 400 & 2.400 \\
\hline & 2 & Land & & & & 750 \\
\hline & 3 & Building & & & & 100 \\
\hline & 4 & Machines & & & & 700 \\
\hline & 5 & Tools and equipment & & & & 150 \\
\hline & 6 & Construction of water wells & & 1 & 500 & 500 \\
\hline & 7 & Californian earthworms (kg) & & 120 & 9 & 1.080 \\
\hline & I & Total FIXED costs: & 73.77 & & & 5.680 \\
\hline \multirow{11}{*}{2} & \multicolumn{2}{|c|}{ Variable costs } & & & & \\
\hline & \multirow{3}{*}{ II } & Material costs (unit of measure) & $15.84 \%$ & & & 1.220 \\
\hline & & Earthworm food - manure $\left(\mathrm{m}^{3}\right)$ & & 120 & 8.5 & 1.020 \\
\hline & & Energy, water for watering... & & & & 200 \\
\hline & \multirow{7}{*}{ III } & Labor costs (employee) & $10.39 \%$ & & & 800 \\
\hline & & Filling of facilities & & & & 200 \\
\hline & & Separation of earthworms & & & & 150 \\
\hline & & Watering & & & & 50 \\
\hline & & Waste collection & & & & 100 \\
\hline & & Sifting & & & & 200 \\
\hline & & Manipulation & & & & 100 \\
\hline \multirow[t]{3}{*}{3} & IV & Interest on working capital & & & & 0 \\
\hline & $\mathrm{V}$ & Total VARIABLE COSTS (II+ III+ IV): & 26.23 & & & 2.020 \\
\hline & VI & Total cost of production $(\mathrm{I}+\mathrm{V})$ & $100 \%$ & & & 7.700 \\
\hline
\end{tabular}


The shown total production cost $(€ 7,770)$ relates to $84,000 \mathrm{~L}$ of the finished product.

Fixed costs are the basic means of starting a manufacturing process. The fixed costs in relation to the total costs in the first year are $73.77 \%$, while variable costs are $26.23 \%$ compared to total costs in the first year of production (Table 1).

Fixed costs in the first year of production can be much lower if cheaper materials are used for the construction of earthworm facilities (as is the case in some eastern states with other climatic conditions and business habits). Cheap bedding is made of: pvc material, wood planks, used sheet metal, barrels and no concrete floor.

The share of variable costs (food for earthworms, energy and water consumed, labor costs) is $15.84 \%$, while labor costs are $10.39 \%$ compared to the total working capital of production (26.23\%). The earthworms are from their own production in each subsequent production year.

Considering that the countries of the Asian continent have a long tradition in the production of vermicompost, it is realistic to expect other results in the economic analysis of this type of production in them.

To study the economics of production and sales of vermicompost in Chitvan, Nepal, the following data were obtained: According to Practical Action Nepal (2008), the variable cost and fixed cost comprised about $68 \%$ and $32 \%$ of the total cost of production, respectively (Deepa Devkota et al., 2017).

The total cost of producing vermicompost was derived by adding variable costs and fixed costs. Most vermicompost manufacturers have used the variable inputs available at home to produce vermicompost. Variable costs and fixed costs accounted for about $78.80 \%$ and $21.20 \%$ of total production costs, respectively (Ashfaq et al., 2017)

Total variable costs which primarily comprised material costs accounted for 70.59 per cent of total costs. Material costs which arose on account of procurement of earthworms, bedding material, worm feed and watering were as high as 77.95 per cent of total variable costs. Labor costs which accounted for around 13.96 per cent of the total variable costs were incurred for filling of pits, separation of worms, watering, waste collection and sieving. Interest on working capital accounted for around 8.09 per cent of the total variable costs (Thiripurasundari and Divya, 2017).

Since vermicompost is an inexpensive product, a large load within variable costs is the packaging and transportation of the finished product.

In economic terms marketing and sales costs are part of the working capital in the cost-benefit analysis.
Table 2

Cost structure of marketing and sales in the first year

\begin{tabular}{|c|l|c|c|}
\hline \multicolumn{2}{|l|}{$\begin{array}{l}\text { Cost structure of marketing } \\
\text { and sales }\end{array}$} & $€ 2,450$ & $100 \%$ \\
\hline 1 & Analyses - certificate & 250 & 10.2 \\
\hline 2 & Packaging(20 L) & 1.280 & 52.24 \\
\hline 3 & $\begin{array}{l}\text { Handling (loading / } \\
\text { unloading) }\end{array}$ & 200 & 8.16 \\
\hline 4 & Transport & 420 & 17.14 \\
\hline 5 & Storage & 100 & 4.08 \\
\hline 6 & Marketing & 150 & 6.12 \\
\hline 7 & Other & 50 & 2.04 \\
\hline
\end{tabular}

The above data on total marketing and sales expenses $(€ 2,450)$ for $84,000 \mathrm{~L}$ vermicompost show that the costs of packaging (52.24\%) and transport $(17.14 \%)$ make up the largest shares, as presented in Table 2. The packaging was done in $20 \mathrm{~L}$ pvc bags.

This is due to the low cost of vermicompost as a finished product.

Table 3

Total Costs in the first year of production

\begin{tabular}{|l|l|c|c|}
\hline Item & Total Costs (A+B) & $€ 10,150$ & $100 \%$ \\
\hline 1 & Production Costs (A) & 7,700 & $75.86 \%$ \\
\hline 2 & $\begin{array}{l}\text { Marketing and Sales } \\
\text { Costs (B) }\end{array}$ & 2,450 & $24.13 \%$ \\
\hline
\end{tabular}

The share of production costs in the structure of total costs of the first production year is high and amounts to $75.86 \%$ (Table 3 ).

\section{Table 4}

Sales price structure of finished vermicompost in the first year of production

\begin{tabular}{|c|c|c|c|c|}
\hline Item & \multicolumn{2}{|c|}{ Sales price structure } & $€ / 000 \mathrm{~L}$ & $\%$ \\
\hline I & \multicolumn{2}{|c|}{ Selling price } & 170 & 100 \\
\hline \multirow{3}{*}{ II } & \multicolumn{2}{|c|}{ Total Costs $(1+2)$} & 120.83 & 71.08 \\
\hline & 1 & $\begin{array}{l}\text { Production } \\
\text { Costs }\end{array}$ & 91.66 & \\
\hline & 2 & $\begin{array}{l}\text { Marketing and } \\
\text { Sales Costs }\end{array}$ & 29.17 & \\
\hline III & \multicolumn{2}{|c|}{ Profit I- II) } & 49.17 & 28.92 \\
\hline
\end{tabular}

The price at which the manufacturer puts the finished product on the market of the Republic of Serbia is $€ 170 / 1,000 \mathrm{~L}$ vermicompost, while the profit per $1,000 \mathrm{~L}$ vermicompost is $€ 49.17$, as shown in Table 4. 
Table 5

Production costs in the second year

\begin{tabular}{|c|c|c|c|c|c|c|}
\hline \multirow{2}{*}{ Item } & \multirow{2}{*}{\multicolumn{2}{|c|}{ Description }} & \multicolumn{4}{|c|}{ Production price of vermicompost } \\
\hline & & & $\%$ & Quantity & Price & $€$ \\
\hline \multirow[t]{9}{*}{1} & \multicolumn{2}{|c|}{ Fixed costs (basic investment costs) } & & & & \\
\hline & 1 & Earthworm facilities & & & & 0 \\
\hline & 2 & Land & & & & 0 \\
\hline & 3 & Building & & & & 0 \\
\hline & 4 & Machines & & & & 0 \\
\hline & 5 & Tools and equipment & & & & 0 \\
\hline & 6 & Construction of water wells & & & & 0 \\
\hline & 7 & Californian earthworms (kg) & & & & 0 \\
\hline & $\mathrm{I}$ & Total FIXED costs: & 0 & & & 0 \\
\hline \multirow[t]{11}{*}{2} & \multicolumn{2}{|c|}{ Variable costs } & & & & \\
\hline & \multirow{3}{*}{ II } & Material costs (unit of measure) & $60.40 \%$ & & & 1,220 \\
\hline & & Earthworm food - manure $\left(\mathrm{m}^{3}\right)$ & & 120 & 8.5 & 1,020 \\
\hline & & Energy, water for watering... & & & & 200 \\
\hline & \multirow{7}{*}{ III } & Labor costs (employee) & $39.60 \%$ & & & 800 \\
\hline & & Filling of facilities & & & & 200 \\
\hline & & Separation of earthworms & & & & 150 \\
\hline & & Watering & & & & 50 \\
\hline & & Waste collection & & & & 100 \\
\hline & & Sifting & & & & 200 \\
\hline & & Manipulation & & & & 100 \\
\hline \multirow[t]{3}{*}{3} & IV & Interest on working capital & & & & 0 \\
\hline & $\mathrm{V}$ & Total VARIABLE COSTS (II+ III+ IV): & & & & 2,020 \\
\hline & VI & Total cost of production $(\mathrm{I}+\mathrm{V})$ & $100 \%$ & & & 2,020 \\
\hline
\end{tabular}

Because there are no fixed asset investments in the second year of production, there are only variable costs (working capital of production), which are also the total cost of production in the second year: $€ 2,020$ also for $84,000 \mathrm{~L}$ of the finished product (Table 5).

\section{Table 6}

Cost structure of marketing and sales in the second year

\begin{tabular}{|c|l|c|c|}
\hline \multicolumn{2}{|l|}{$\begin{array}{l}\text { Cost structure of } \\
\text { marketing and sales }\end{array}$} & $€ 2,450$ & $100 \%$ \\
\hline 1 & Analyses - certificate & 250 & 10.2 \\
\hline 2 & Packaging (20 L) & 1,280 & 52.24 \\
\hline 3 & $\begin{array}{l}\text { Handling (loading / } \\
\text { unloading) }\end{array}$ & 200 & 8.16 \\
\hline 4 & Transport & 420 & 17.14 \\
\hline 5 & Storage & 100 & 4.08 \\
\hline 6 & Marketing & 150 & 6.12 \\
\hline 7 & Other & 50 & 2.04 \\
\hline
\end{tabular}

As shown, marketing and sales costs are the same as in the first year of production, given the same amount of the finished product (Table 6).

Table 7

Total Costs in the second year

\begin{tabular}{|l|l|c|c|}
\hline Item & Total Costs ( A+B) & $€ 4,470$ & $100 \%$ \\
\hline 1 & Production Costs (A) & 2,020 & $45.19 \%$ \\
\hline 2 & $\begin{array}{l}\text { Marketing and Sales } \\
\text { Costs (B) }\end{array}$ & 2,450 & $54.81 \%$ \\
\hline
\end{tabular}

Production costs in the second production year are $€ 2,020$, accounting for $45.19 \%$ of total costs. These costs are far lower than in the first production year: $€$ 7,700 or $75.76 \%$ of the total cost of production, as shown in Table 7.

Since marketing and sales costs in the second year are the same as in the first year, the profit in the second year is € 117,14 / $000 \mathrm{~L}$ (Table 8). 


\section{Table 8}

Sales price structure of finished vermicompost in the second year of production

\begin{tabular}{|l|l|l|c|c|}
\hline Item & Sales price structure & $€ / 000 \mathrm{~L}$ & $\%$ \\
\hline I & Selling price & 170 & 100 \\
\hline \multirow{3}{*}{ II } & \multicolumn{2}{|l|}{ Total Costs (1+2) } & 52.86 & 31.09 \\
\cline { 2 - 5 } & 1 & Production Costs & 23.89 & \\
\cline { 2 - 5 } & 2 & $\begin{array}{l}\text { Marketing and } \\
\text { Sales Costs }\end{array}$ & 28.97 & \\
\hline III & \multicolumn{2}{|l|}{ Profit (I- II) } & 117.14 & 68.91 \\
\hline
\end{tabular}

The total cost in the first year of production is $€$ 10,150 (Table 3 ); in the second year of production: $€$ 4,470 (Table 7).

The profit in the first year: $€ 4,130$ (84 x € 49.17), while in the second year the profit: $€ 9,840$ (84 x € 117.14) with the finished product of: $84,000 \mathrm{~L}$ in both first and second production year. The above results indicate that this is an extremely profitable production.

In addition to the economic benefits to the manufacturer, the observed product has certain economic benefits and benefits for the buyer (which may be part of the sales channel or end user) as well as the wider community.

Some of the benefits to the wider community in increasing the production of vermicompost are: increasing social responsibility for environmental protection, because bio-waste $s$ an excellent medium for the production of vermicompost; gradual transition towards safer agricultural production without potential contaminants; repair of soil structure that is severely degraded and acidified; employment of new labor in this segment of agricultural production (production, distribution, sales); the survival of the population in rural areas in the Republic of Serbia; faster and planned development of organic production, thus creating greater added value for domestic agricultural products.

Planning global organic farming and sustainable agriculture can truly bring in 'economic prosperity' for the farmers, 'ecological security' for the farms and 'food security' for the people. This will require embarking on a 'Second Green Revolution' and this time through 'Vermiculture Revolution' by the earthworms. This practice will ensure economic viability and environmental sustainability (Hussaini, 2013).

As for the benefits for vermicompost consumers themselves, here are just a few: easier vermicompost manipulation; increased yield, higher resistance and better health of treated crops; vermicompost does not contain heavy metals and nematodes; vermicompost has a prolonged effect over several years; there is no possibility of overdosing the plants by its use.

\section{Conclusion}

Fixed costs in the first year of production can be much lower if cheaper materials are used for the construction of earthworm facilities (as is the case in some eastern states with other climatic conditions and business habits). The Ministry of Agriculture of the Republic of Serbia will not stimulate the production of vermicompost for the time being, so the entire production is not planned for now.

Producers of vermicompost in Serbia do not have any assistance in setting up a bio-waste processing plant, which slows down the development of this method of bio-waste processing.

The study indicated that vermicompost is a profitable enterprise with better net profits and a better benefitcost ratio. The financial viability study showed that vermicompost production is a feasible enterprise. An appropriate supply chain of organic waste and cow dung can attract people to produce vermicompost on a large scale. In addition to the economic benefit to the manufacturer, the product under consideration has certain economic benefits and benefits for the customer (who may be part of the sales channel or end user) as well as the wider community. Some of the benefits to the wider community in increasing the production of vermicompost are: increasing social responsibility for environmental protection, because bio-waste is an excellent medium for the production of vermicompost; gradual transition towards safer agricultural production without potential contaminants; repair of soil structure that is severely degraded and acidified; employment of new labor in this segment of agricultural production (production, distribution, sales); the survival of the population in rural areas in the Republic of Serbia; faster and planned development of organic production, thus creating greater added value for domestic agricultural products. As for the benefits for vermicompost consumers, here are just a few: simpler vermicompost manipulation; increased yield of treated crops, greater resistance and better health of treated crops; no heavy metals and nematodes in the finished product; has a prolonged effect over many years; there is no possibility of overdosing the plants by its use.

The production, sale and use of vermicompost is the basis of a "circular economy", where the movement of organic matter in nature is constantly evolving and transforming into a new product. Biowaste is thus recycled with the help of Californian worms into natural, high quality material with new added value.

The obtained results indicated that, in the Republic of Serbia, a systematic and faster work should be done to raise people's awareness of vermicompost production through the application of the best engineering solutions in this segment of agricultural production, since this will become a fast growing segment of agricultural production.

Vermicompost is widely used in primary agricultural production: fruits and vegetables, mushroom production, horticulture, nurseries, green areas, parks, green sports fields, and in all segments of organic plant production.

\section{References}

Abdullahi, H. (2013). Vermiculture bio-technology: An effective tool for economic and environmental sustainability. African Journal of Environmental Science and Technology, 7(2), 56-60.

Ashfaq, A.K.M., Acharjee, D.C., Islam, B., Mohoshinul, S., Shawon, H., Hossain, M.I. (2017). Financial profitability of vermicompost in Fulbaria Upazila of Mymensingh district. IOSR Journal of Agriculture and Veterinary Science, 10(10), 57-61.

Deepa, D., Dhakal, SC., Dhakal, D.D., Ojha, RB., (2014). Economics of Production and Marketing of Vermicompost in Chitwan, Nepal. International Journal of Agricultural and Soil Science, 2(7), 112-117.

Dominguez, J. (2004). State-of-the-Art and New Perspectives on Vermicomposting Research. Departamento de 
Ecoloxfa e Bioloxfa Animal, Universidade de Vigo, Spain. CRC Press LLC.

Dragović, R. (2012). Iskorištavanje biljnih otpadaka u svrhu gnojidbe. www. agroklub.com. Accessed February 10, 2020.

Hussaini, A. (2013). Vermiculture bio-technology: An effective tool for economic and environmental sustainability. African Journal of Environmental Science and Technology. $7(2), 56-60$.

List of plant nutrition products and soil improvers (approved by the Ministry of Agriculture of the Republic of Serbia in December 2018. Accessed February 10, 2020 Organic production in Organic production in Serbia (2017) Serbia organica. Accessed February 10, 2020.

Karmakar, S., Lague, C., Agnew, J., Landry, H. (2007) Integrated decision support system (DSS) for manure management: A review and perspective. Computers and Electronics in Agriculture, 57(2), 190-201.

Loncaric, Z., Engler, M., Karalić, K., Bukvić, G., Lončarić, R., Kralik, D. (2005). Ocjena kvalitete vermikompostiranog goveđeg stajskog gnoja. Poljoprivreda, 11(1), 57-63.

Stepanov, J. (2018). Model za evaluaciju sistema upravljanja komunalnim otpadom primenom metode ocenjivanja životnog ciklusa. Doktorska disertacija, Fakultet tehničkih nauka, Novi Sad, Srbija.

Thiripurasundari, K., Divya, S.V. (2017). Cost and return structure of vermicompost production and marketing in Tirunelveli district. EPRA International Journal of Economic and Business Review, 5(1), 120-122.

Vukobratovic, M. (2008). Proizvodnja i ocjena kvalitete kompostiranih stajskih gnojiva. Doktorski rad. Poljoprivredni fakultet u Osijeku. Osijek. Hrvatska. 